\title{
Morphological and phytochemical characterization of Piper hispidinervum DC. and Piper aduncum L. populations in the state of Acre ${ }^{1}$
}

\author{
Jacson Rondinelli da Silva Negreiros ${ }^{2}$, Daniela Popim Miqueloni*3 \\ http://dx.doi.org/10.1590/0034-737X201562010010
}

\begin{abstract}
Because of the increasing demand of the industry for the production of essential oils, studies highlight the genetic variability of Piper hispidinervum and P. aduncum species according to their patterns of spatial distribution, showing the Amazon region as the source of superior genetic material in the production of safrole and dillapiole. Thus, the objective this study was to characterize the morphology and the phytochemistry of Piper hispidinervum and $P$. aduncum populations in the Active Germplasm Bank of Embrapa Acre to generate subsidies for the genetic improvement of these species. The results showed that the average values for leaf width and length were 141.67 and $48.04 \mathrm{~mm}$, and petioles length and diameter measurements were 2.83 and $1.78 \mathrm{~mm}$ for P. hispidinervum and 189.22; 67.74; 6.03 and $2.22 \mathrm{~mm}$ for $P$. aduncum respectively. The average height and canopy volume measurements were $2.39 \mathrm{~m}$ and $6.30 \mathrm{~m}^{3}$ and $2.70 \mathrm{~m}$ and $7.78 \mathrm{~m}^{3}$ respectively for each species. For $P$. hispidinervum, the population with higher performance indried yield and content of safrole was population 02 , with $3.9 \%$, and the population 04 showed 94.3\% safrole content, both with genetic material from the region of Acrelândia and Plácido de Castro. To P. aduncum, the populations with better performance were 207, 208 and 209, forming a homogeneous group with dried yield average of $3.8 \%$ and dillapiol content of $84-85 \%$. Such populations are indicated for selection in breeding program of these species due to better performance.
\end{abstract}

Keywords: morphology, dried yield, dillapiole and safrole content.

\section{RESUMO}

\section{Caracterização morfológica e fitoquímica de populações de Piper hispidinervum DC. e Piper aduncum L. no Acre}

Estimulados pela crescente demanda da indústria pela produção de óleos essenciais, estudos ressaltam a variabilidade genética das espécies de Piper hispidinervum e P. aduncum, de acordo com seus padrões espaciais de distribuição, mostrando-se a região Amazônica como origem de materiais genéticos superiores para a produção de safrol e dilapiol. Objetivou-se, com este trabalho, caracterizar morfológica e fitoquimicamente populações de Piper hispidinervum e de P. aduncum, do Banco Ativo de Germoplasma da Embrapa Acre, de forma a gerar subsídios para o melhoramento genético das espécies. Os resultados mostraram que os valores médios para largura e comprimento de folha e comprimento e diâmetro de pecíolo foram: 141,$67 ; 48,04 ; 2,83$ e 1,78 mm, respectivamente, para $P$. hispidinervum, e 189,$22 ; 67,74 ; 6,03$ e $2,22 \mathrm{~mm}$, para $P$. aduncum. Os valores médios de altura e volume de copa foram $2,39 \mathrm{~m}$ e $6,30 \mathrm{~m}^{3}$ e $2,70 \mathrm{~m}$ e $7,78 \mathrm{~m}^{3}$, respectivamente, para cada espécie. Para $P$. hispidinervum, as populações com maior desempenho no rendimento em base livre de umidade (BLU) e teor de safrol foram 02 , com 3,9\% de rendimento e 04 com 94,3\% de safrol, ambas com material genético originário das

\footnotetext{
Submitted on 05/08/2013 and approved on 09/17/2014.

${ }^{1}$ Financial support: Embrapa and CNPq.

2Embrapa Acre, Rio Branco, Acre, Brazil. jacson.negreiros@embrapa.br

${ }^{3}$ Embrapa Acre, Rio Branco, Acre, Brazil. DTI-B/CNPq fellowship holder. danimique @yahoo.com.br

Corresponding author: danimique@yahoo.com.br
} 
regiões de Acrelândia e Plácido de Castro. Para P. aduncum, as populações com melhor desempenho foram 207, 208 e 209, originárias da Microrregião de Cruzeiro do Sul, formando um grupo homogêneo, com rendimentos em BLU médios de 3,8\% e teor de dilapiol de 84 a $85 \%$. Essas populações de melhor desempenho são indicadas para seleção, no programa de melhoramento genético das espécies.

Palavras-chave: morfologia, rendimento em BLU, teor de safrol e dilapiol.

\section{INTRODUCTION}

The Amazon is a great source of natural products for various human uses. Essential oils, secondary metabolite compounds produced by several plants, are part of such products and play biological and flavoring activities (Andrade et al., 2009). Among the largest producers of oil are the Piperaceae, widely used in medical and agronomic uses in many countries (Hartemink \& Sullivan, 2001; Yoneda, 2006; Celis et al., 2008). Among the most commonly species used as essential oils producers are Piper hispidinervum and P. aduncum, from which safrole and dillapiole are extracted, respectively. The first presents proven insecticidal activity (Estrela et al., 2006; Fazolin et al., 2007; Celis et al., 2008) and the second, molluscicide, antimicrobial, plasmodicide, fungicide, larvicide, insecticide and synergistic activities (Andrade et al., 2009), and medical use as a diuretic, hemostatic, stomachic, astringent and balsamic (Guimarães \& Giordano, 2004).

The wide application of these products attracts the attention of producers and industry, which increases the demand for their exploitation and obtaining improved cultivars for the introduction of these species in agricultural systems, especially in the Amazon region (Gaia et al., 2004). Several studies point to the genetic diversity of these species, in which $P$. hispidinervum shows higher yields and safrole contents in the Amazon region (Andrade et al., 2009). Because of its high adaptability to different climatic and soil characteristics and a very efficient propagation mechanism (Lepš et al., 2002) P. aduncum presents chemotypes that, according to Almeida et al. (2009) are distributed in the Amazon region and Atlantic Forest. However, studies show that its variability is still large inside the Amazon region itself, with distinct genotypes distributed by the states of Amazonas and Pará (Gottlieb et al., 1981).

The essential oil is obtained from the extraction of aerial biomass and, according to the $P$. hispidinervum production system, cuts are recommended every 12 months (Bergo et al., 2002), which is also adopted for $P$. aduncum since it does not present a particular production system. Thus, the choice of genotype should also favor the good regrowth and regeneration capacity as well as formation and canopy volume since productivity is tied to the volume of biomass for extraction according to the performance and major component content of the oil, which is well accepted by the industry at levels above $90 \%$ (Silva \& Oliveira, 2000).

The objective of this study was to characterize the morphologic and phytochemical traits of Piper hispidinervum and $P$. aduncum populations in the Active Germplasm Bank (AGB) of Embrapa Acre in order to generate data for the genetic improvement of the species.

\section{MATERIAL AND METHODS}

In order to characterize elements of the Active Germplasm Bank (AGB) of Embrapa Acre, in the city of Rio Branco-AC, 14 populations of Piper hispidinervum and nine populations of $P$. aduncum grown in a $2 \times 2 \mathrm{~m}$ spacing were analyzed. Each individual was analyzed for leaf morphological characteristics such as width and length (in $\mathrm{mm}$ ) and diameter and length of the petiole (in $\mathrm{mm}$ ), and also of the canopies, such as height and canopy diameter (in $\mathrm{cm}$ ), and phytochemical moisture characteristics, yield in moisture-free basis and major component content of the essential oil of each species, based on green matter (in \%). The morphological characteristics were measured with tape measure, for the canopy variables, and with the caliper to the leaf variables. The canopy volume was estimated using the formula: $\mathrm{V}$ $=2 / 3 \pi R^{2} H$, where $\mathrm{R}=$ mean radius of the canopy and $\mathrm{H}=$ plant height (Ledo et al., 1999).

The phytochemical characteristics were analyzed in Essential Oils Laboratory of Embrapa Acre. For determining the contents of safrole and dilapiolle, the essential oils were extracted by the cohobation or condensate water recirculation method (Heath, 1977). For the extraction, samples of $90 \mathrm{~g}$ of chopped green biomass were used for each individual of the population of both species, mixed with $450 \mathrm{ml}$ of distilled water and submitted towater boiling temperature $\left(100^{\circ} \mathrm{C}\right)$ in heating mantle, for 180 minutes, where the densest collected fraction was consisted of oil.

The quantification of dilapiolle and safrole contained in the essential oil, for Piper hispidinervum and $P$. aduncum, respectively, was carried out in the HewlettPackard gas chromatograph, Model 6890 (Wilmington, USA) equipped with a flame ionization detector and 
capillary column of $30 \mathrm{~m}$ in length and $25 \mathrm{~mm}$ of internal diameter. Helium was used as carrier gas, while the internal injector and detector were maintained at a temperature of $250^{\circ} \mathrm{C}$ and "split" of approximately 1:100. The initial oven temperature was maintained at $80^{\circ} \mathrm{C}$ for 10 minutes with $4^{\circ} \mathrm{C}$ increments per minute up to $140^{\circ} \mathrm{C}$ and thereafter, increments of $20^{\circ} \mathrm{C}$ per minute up to $260^{\circ} \mathrm{C}$, being programmed for up to $260^{\circ} \mathrm{C}$.

To calculate yield in moisture-free basis, the moisture content of biomass was determined. This moisture content was achieved on the basis of the immiscibility of the solvent (toluene) and water contained in the green matter (Figueirêdo et al., 2004). Six grams of chopped green biomass of each individual were used, mixed in round bottom flask with a capacity of $250 \mathrm{ml}$. Through the top of the condenser, $80 \mathrm{~mL}$ of toluene was added to allow the return of the solvent to the flask and exposed under heating mantle, at a temperature of about $120^{\circ} \mathrm{C}$. Then, reading of the amount of the water extracted from biomass was performed.

The essential oil yield obtained in the laboratory was calculated based on green matter in moisture-free basis, according to Santos et al. (2004). The value calculated as a percentage corresponds to the volume/weight relationship and indicates the correct amount of oil in the green biomass. The yield data in moisture-free basis was regarded as $100 \%$ in the laboratory.

The results of the morphological characterization and phytochemical analysis of individuals per population for each species, were submitted to analysis of variance (Anava) and comparison of means by the Tukey test at $5 \%$ probability, in order to compare populations within species. It was used the completely randomized design with ten repetitions (individuals) per population. The Pearson linear correlation test was used to determine the dependence degree of each variable among the populations of the species (Ferreira, 2008). The cluster analysis was carried out by the hierarchical method, considering the simple Euclidean distance and Ward's method, with moisture values, yield in moisture-free basis and major component content of the essential oil to determine homogeneous groups of populations for each species (Hair et al., 2005) and associate them with its spatial distribution of origin. Analyses were processed by Statistica 7.0 (Statsoft, 1995).

\section{RESULTS AND DISCUSSION}

The analysis of variance showed significant differences $(p<0.05)$ for phytochemical and morphological characteristics analyzed for both species (Table 1). These characteristics were associated with the location data of the collection of genetic material for both species, indicating patterns of behavior regarded to the yield in moisture-free basis and the amounts of safrole and dilapiolle. The results found in this study were similar to those found by Silva \& Oliveira (2000), who observed that the safrole producer species, $P$. hispidinervum, located in the Mesoregion of Acre Valley, including the municipalities of Acrelândia and Plácido de Castro (Rio Branco microrregion), and Brasiléia and Assis Brazil (Brasiléia Microregion), on the east part of the state. However, dilapiolle producer species, $P$. aduncum, is concentrated in the Mesorregion of Vale do Juruá, micro-region of Cruzeiro do Sul, in the municipalities of Cruzeiro do Sul and Rodrigues Alves (Figure 1). These figures show the combination of morphological features to physiographic factors, focusing each species in regions of different patterns.

For $P$. hispidinervum, there was a significant difference only between the means of morphological characteristics, average height and canopy volume (Table 1), in the region of Brasiléia, which presented significantly lower values, especially for populations 07 , 10 and 15. Significant positive correlations were found for diameter of the petiole and leaf width and diameter of the petiole and leaf length and leaf; yield and moisture and height and volume of canopy (Table 2). Miranda et al. (2002) also found a significant correlation between plant height and biomass production, mainly canopy diameter in native populations, suggesting a pattern of aerial part formation of the species regardless of the form of cultivation. Neverthless, Figueirêdo et al. (2004) found a significant negative correlation for yield and moisture and positive for yield and safrole content in dry biomass. These results indicate that, for dry biomass, moisture generally reduces the amount of extracted oil, as well as the major compound content of the essential oil.

Regarding $P$. aduncum, the leaf morphologic characteristics also showed little variation, except for the populations 200 and 203, presenting significantly lower values of length of the petiole (Table 3 ). The height and volume of the canopy were significantly higher for the populations 014, 015, 200 and 202. The correlations observed showed significant coefficients for diameter of the petiole and leaf width, diameter of the petiole and leaf length and leaf width and length (Table 4). These correlations are important because they allow us to infer the quality of essential oil, since the highest levels of the major compound are concentrated in the leaves (Figueirêdo et al., 2004).

The means of morphological characteristics observed in these components of the Active Germplasm Bank (AGB) for 14 populations of $P$. hispidinervum (Table 1), showed values similar to those reported by Silva \& 


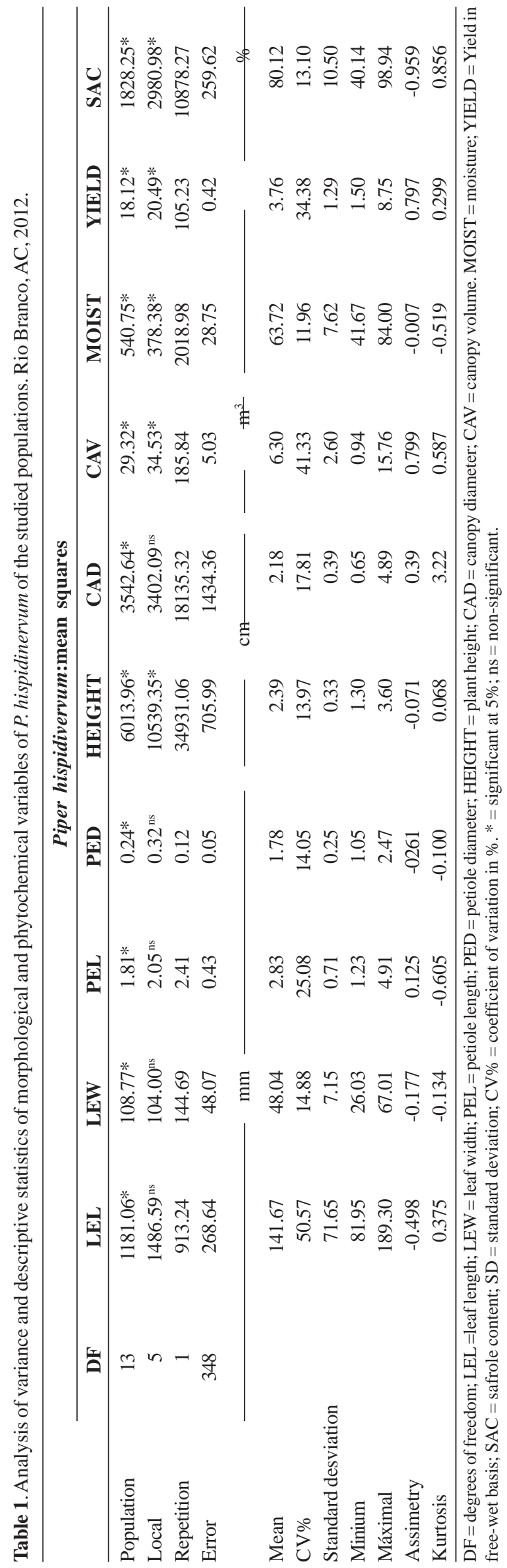

Oliveira (2000). This species is characterized as a nonpubescent branches shrub, with petioles with 1 to $2 \mathrm{~mm}$ and oblong-lanceolate or oblong-elliptical leaves, 145$222 \mathrm{~mm}$ long and $47 \mathrm{~mm}$ wide. The same can be observed for $P$. aduncum in the AGB, through the analysis of nine populations (Table 3), described as shrubs with elliptical or lanceolate leaves, about $200 \mathrm{~mm}$ long and $70 \mathrm{~mm}$ wide and 2 to $4 \mathrm{~mm}$ petioles (Silva \& Oliveira 2000).

Out of the 14 populations of $P$. hispidinervum, only five were above average for the leaf morphological values, which were 07, 19, 22, 26 and 29. For $P$. aduncum, among the nine populations studied, only the 014 had values above average.

The characterization of the canopy morphology of individuals is of great importance since it brings estimates of the aerial biomass yield, which affects the production of essential oil according to the yield and contents of the major compounds. This information provides grants for identification and subsequent selection of superior populations that will support the breeding program. As a result, for the populations of $P$. hispidinervum present in $\mathrm{ABG}$, the average of the estimated canopy volume was $6.30 \mathrm{~m}^{3}$, with an average height of $2.39 \mathrm{~m}$ and canopy diameter of $2.18 \mathrm{~m}$ (Table 1). As for the populations of $P$. aduncum, the average volume and height observed were higher, with an average canopy volume of $7.78 \mathrm{~m}^{3}, 2.70 \mathrm{~m}$ of height and $2.32 \mathrm{~m}$ canopy diameter (Table 3). Under native conditions, without management or pruning for canopy formation, Miranda et al. (2002) observed more frequency for the 1-10 individual class every $100 \mathrm{~m}^{2}$, with average values of canopy height and diameter of 5.07 and $2.10 \mathrm{~m}$, respectively. However, there was a concentration of leaves and thin branches in the upper third of the canopy, making it difficult to cut. The coefficient of variation (CV\%) of the morphological variables was considered high (> 30\%) for leaf length and canopy volume, and

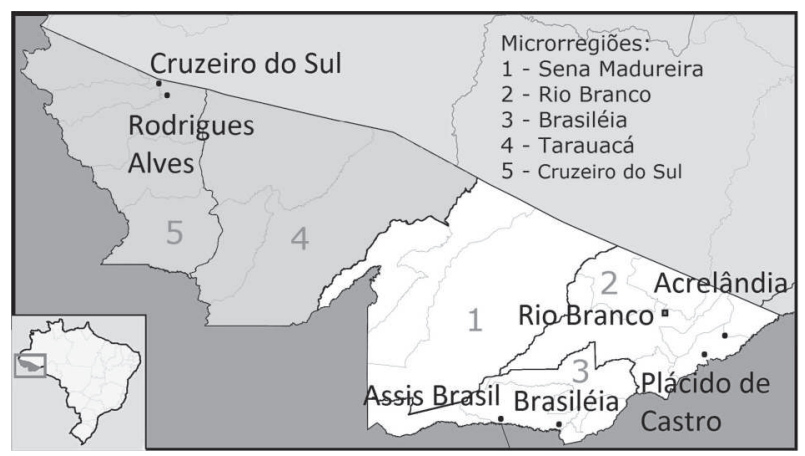

Figure 1. Location of meso and microregions and the source municipalities of the genetic material of Piper hispidinervum and P. aduncum in. Acre Valley mesoregion: $1=$ Sena Madureira, $2=$ Rio Branco, 3 = Brasiléia; Juruá mesoregion: 4 = Tarauacá, 5 = Cruzeiro do Sul. 
medium $(20 \%<\mathrm{CV} \%<30 \%)$, for petiole length in $P$. hispidinervum (Table 1), and medium for length of petiole and canopy volume for P. aduncum (Table3) (Ferreira, 1991).

Parallel to the morphological analysis, the phytochemical characterization provides qualitative information of the production of essential oils, complementing subsidies for the selection of higher genetic material. For the values of moisture, $P$. hispidinervum showed an average of $63.72 \%$ (Table 1); however P. aduncum presented an average of $70.82 \%$ (Table 3). According to Pimentel et al. (2006), determining the moisture content of the material to be distilled is of great importance because it allows the comparison of the various yields in moisture-free basis. In this study, for both species, it was 3.76 and $3.88 \%$, respectively, considered at $100 \%$ in the laboratory. For P. aduncum, the populations $014,015,200$, and 207 showed yield in moisture-free basis above average, and for P. hispidinervum, the populations 02, 03, 04, 08, $16,19,29$ and 30 were above the average.

The average contents of safrole and dilapiolle were 80.12 and $74.20 \%$, respectively (Tables 1 and 3). For the Amazon region, studies show dilapiolle contents from 31.5 to $97.3 \%$, with moisture-free basis yields of 0.66 to $3.4 \%$ on dry biomass (Gottlieb et al., 1981; Maia et al., 1998). In general, yield values and essential oil content are higher for extractions dry biomass in relation to the green biomass. This behavior is attributed to the loss of the most volatile minor components with the drying of the material, increasing the concentration of the major component (Smith \& Kassim, 1979). However, the results observed in this study of yield and contents of the major components contents of some compounds show a possible reduction or elimination of the biomass drying step, for both species, which varies from six to eight days (Bergo et al. 2002), without impairs on the extraction of essential oils.
For other regions of the country, these values are considerably smaller, with the presence of other major compounds, suggesting an influence of physiographic and genetic factors in the production of dilapiolle (Mesquita et al., 2005; Navickiene et al., 2006; Potzernheim et al., 2012). Mesquita et al. (2005) suggest environmental interference with the metabolism of the plants due to the remote location of the populations analyzed. On the other hand, Potzernheim et al. (2012) attribute this diversity to gene flow since the distance does not seem to have influenced the chemical composition of the populations they studied. Gaia et al. (2004) suggest that different populations may result from varieties of $P$. aduncum, finding distinct morphological characteristics in the studied populations, corroborating the results of Gottlieb et al. (1981).

For $P$. hispidinervum, because of the endemic occurrence in Acre and Mato Grosso (Andrade et al., 2009), studies have reported moisture-free basis dry biomass yields of $1.8 \%$ and $4.82 \%$ in moisture-free basis and of safrole from $87.0 \%$ to $97.0 \%$ for the Amazon region (Gottlieb et al., 1981; Silva et al., 2002; Estrela et al., 2006) and performance on a wet basis of $0.9 \%$ with safrole content of $18.4 \%$ in the state of Mato Grosso (Andrade et al., 2009).

In order to explore the possible spatial distribution pattern indicated by the ANOVA, the populations were submitted to the hierarchical cluster analysis, based on their phytochemical characteristics, that is, moisturefree basis yield and contents of safrole and dilapiolle (Figure 2 ). For P. hispidinervum, the results suggested that the region of Brasiléia and Assis Brasil form a distinct group (Group 1) from the other populations, which are concentrated in the region of Plácido de Castro and Acrelândia in Rio Branco Micro Region (Group 2). In the first group, the subgroup Brasiléia stands out with lower values, comprising $94.6 \%$ of the individuals in this subgroup. Group 2 consists of the superior

Table 2. Correlation between morphological and phytochemical variables of P. hispidinervum for the populations studied. Rio Branco, AC, 2012

\begin{tabular}{|c|c|c|c|c|c|c|c|c|c|}
\hline & LEL & LEW & PEL & PED & $\mathbf{H}$ & CAD & CAV & MOIS & $\mathbf{Y}$ \\
\hline LEL & $0.675^{*}$ & & & & & & & & \\
\hline PEL & 0.177 & 0.260 & & & & & & & \\
\hline PED & $0.685^{*}$ & $0.524 *$ & 0.120 & & & & & & \\
\hline MOIS & -0.050 & -0.030 & 0.030 & -0.094 & & & & & \\
\hline $\mathrm{Y}$ & -0.137 & -0.095 & 0.034 & -0.193 & 0.806 & & & & \\
\hline SAC & -0.168 & -0.019 & -0.009 & -0.080 & -0.095 & 0.081 & & & \\
\hline $\mathrm{H}$ & 0.104 & 0.196 & 0.114 & 0.205 & -0.027 & 0.002 & 0.235 & & \\
\hline CAD & 0.098 & 0.126 & 0.006 & 0.136 & -0.043 & 0.010 & 0.124 & 0.545 & \\
\hline CAV & 0.131 & 0.202 & 0.063 & 0.198 & -0.035 & 0.022 & 0.197 & $0.798 *$ & $0.841^{*}$ \\
\hline
\end{tabular}

$\mathrm{LEL}=$ leaf length $; \mathrm{LEW}=$ leaf width; $\mathrm{PEL}=$ petiole length $\mathrm{PED}=$ petiole diameter $\mathrm{H}=$ plant height $\mathrm{CAD}=$ canopy diameter; $\mathrm{CAV}=$ canopy volume. MOIS = moisture; $\mathrm{Y}=$ yield in moisture-free; $\mathrm{SAC}=$ safrolle content $; *=$ significant at $5 \%$. 


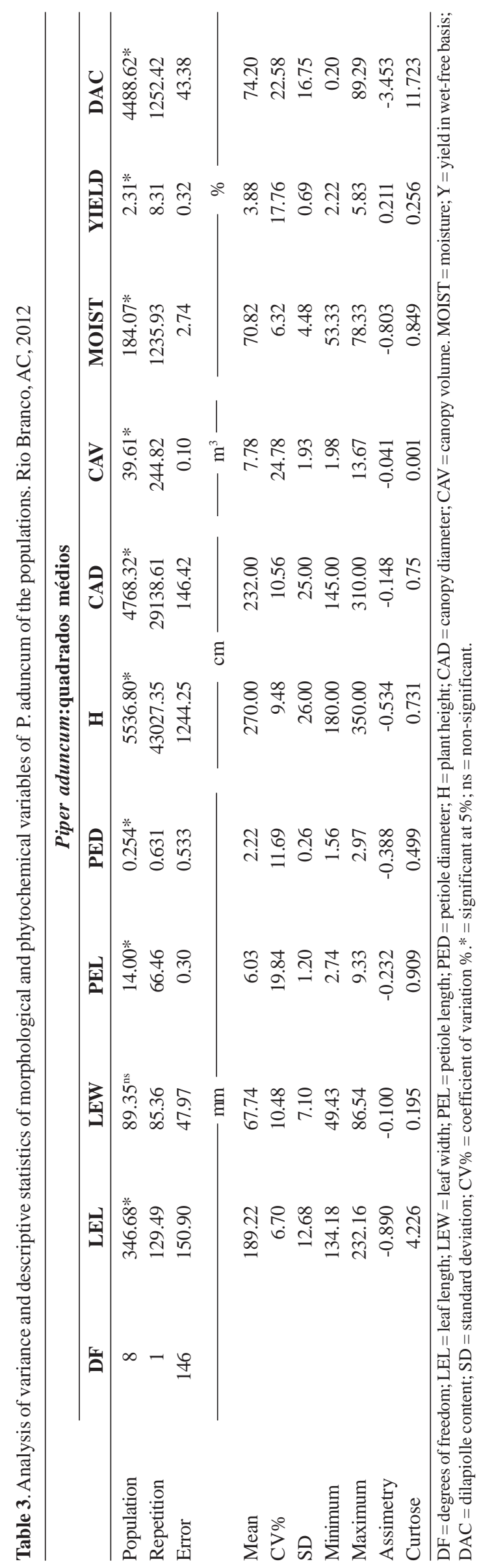

individuals of the population with the highest yields and safrole contents, which was also observed by Wadt \& Kageyama (2004), who analyzed genetic markers of $P$. hispidinervum in Acre and determined two distinct groups according to the genetic distance, present in the microregions of Rio Branco and Brasiléia, behaving more than $20 \%$ of the total genetic variability analyzed in these regions. According to these authors, the distribution of genetic variability is influenced by the reproduction manner, mating system, population size, geographic distribution and gene flow of the species. Due to its low seed production in isolated individuals, the species shows the existence at some degree of selfincompatibility, where further from the mother plant can generate greater number of dispersed seeds.

The cluster tendency of populations according to their geographical locations shows a spatial structure of genetic variability and it is likely that the observed genetic differentiation between populations and regions occur due to the founder effect. This effect suggests that these populations were generated by few original seeds that contain only a small fraction of the total genetic variation of the parental population (Wadt \& Kageyama, 2004).

Regarding the yield of $P$. hispidinervum, populations with the highest significant values are concentrated in the microregion of Rio Branco, between Acrelândia and Plácido de Castro, where the population 02 stands out with $3.9 \%$ of yield moisture-free basis. The highest essential oil content is also in the Acrelândia region, especially in the population 04, with $94.3 \%$ of safrole. However, in the region of Assis Brazil and Brasiléia, in the microregion of Brasiléia, such values were significantly lower, especially for populations 07,10 and 16 with $70.74 \% ; 65.69 \%$ and $62.19 \%$, respectively.

For $P$. aduncum, significant differences in yield were from the populations $014,015,200$ and 207, with means ranging from $4.02 \%$ to $4.08 \%$. The dilapiolle content was significantly greater for populations 207, 208 and 209 , with an average yield of $3.8 \%$, ranging from $84 \%$ to $85 \%$, in the micro-region of Cruzeiro do Sul, and lower for the 202 , with about $14.5 \%$. Cluster analysis of the individuals showed the formation of homogeneous population groups, related dilapiolle content, with the yield and moisture (Figure 3).

Group 1 is formed by population 202, with low dilapiolle content. Group 2 consists of the population 209, 207 and 208, in which the last one forms a distinct subgroup, differentiated by lower moisture; however, it is the group with the best performance with regard to dilapiolle content, as verified by Anava. Group 3 is comprised of the remainder of the populations, 014, 015, 200, 203 and 206, indicating similar features among them. 
Table 4. Correlation between morphological and phytochemical variables of P. aduncum for the studied populations. Rio Branco, AC, 2012

\begin{tabular}{|c|c|c|c|c|c|c|c|c|c|}
\hline & LEL & LEW & PEL & PED & $\mathbf{H}$ & CAD & CAV & MOIST & $\mathbf{Y}$ \\
\hline LEL & $0.864 *$ & & & & & & & & \\
\hline PEL & 0.041 & 0.003 & & & & & & & \\
\hline PED & $0.659 *$ & $0.690 *$ & 0.139 & & & & & & \\
\hline MOIS & 0.033 & 0.060 & 0.369 & 0.148 & & & & & \\
\hline $\mathrm{Y}$ & 0.004 & 0.025 & 0.311 & 0.064 & 0.512 & & & & \\
\hline SAC & 0.366 & 0.314 & 0.461 & 0.205 & 0.069 & 0.320 & & & \\
\hline $\mathrm{H}$ & 0.042 & 0.114 & 0.442 & 0.159 & 0.545 & 0.257 & 0.070 & & \\
\hline CAD & 0.092 & 0.126 & 0.317 & 0.170 & 0.415 & 0.262 & 0.126 & 0.663 & \\
\hline CAV & 0.039 & 0.077 & 0.390 & 0.155 & 0.520 & 0.278 & 0.062 & $0.822 *$ & $0.896^{*}$ \\
\hline
\end{tabular}

$\mathrm{LEL}=$ leaf length; $\mathrm{LEW}=$ leaf width; $\mathrm{PEL}=$ petiole length; $\mathrm{PED}=$ petiole diameter; $\mathrm{H}=$ plant height $\mathrm{CAD}=$ canopy diameter; $\mathrm{CAV}=$ canopy volume. MOIST $=$ moisture $;=$ yield in wet-free basis; $\mathrm{SAC}=$ safrole content $; *$ = significant at a $5 \%$.

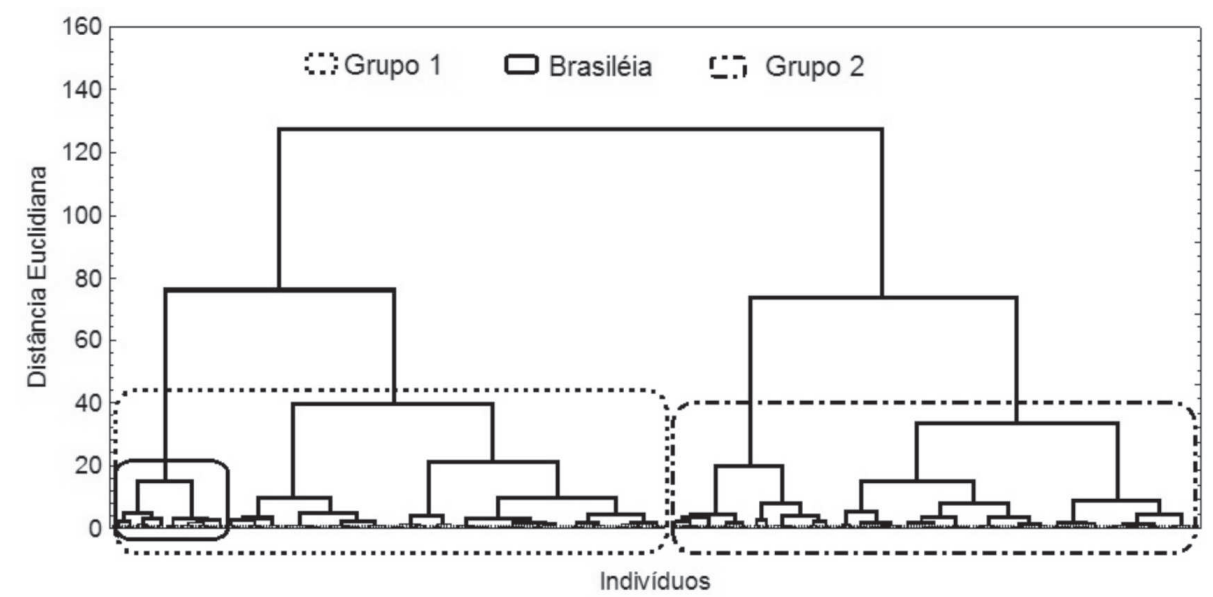

Figure 2. Clustering of P. hispidinervum individuals basedon phytochemical characteristics: Group 1 = Brasiléia and Assis Brasil and Group 2 = Plácido de Castro and Acrelândia regions.

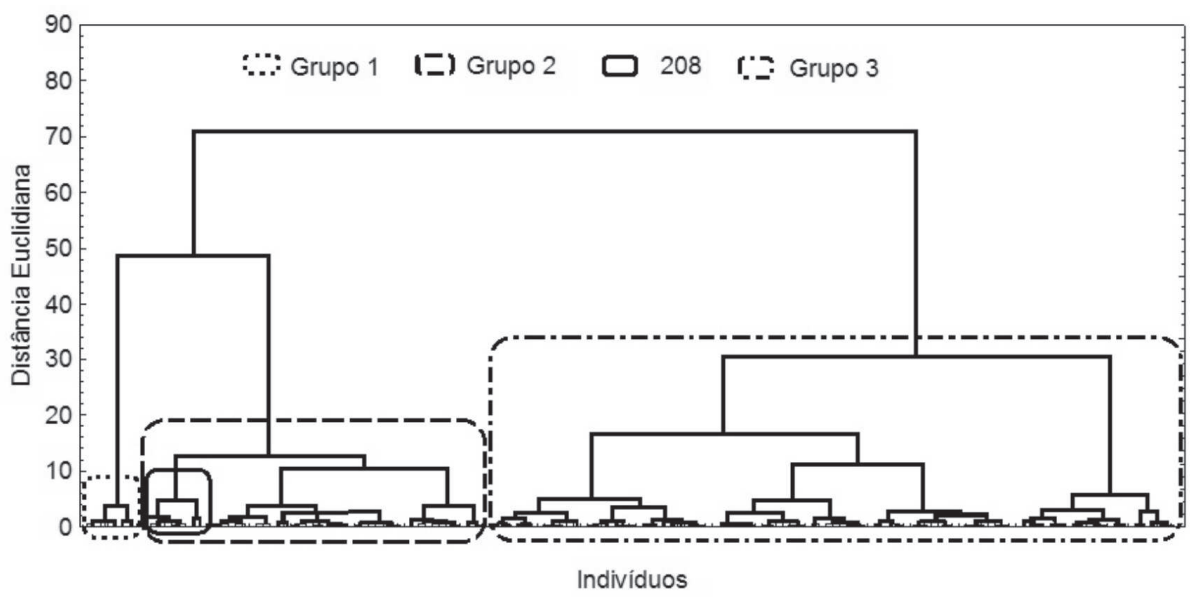

Figure 3. Clustering of P.aduncum individualsbasedon chemicalcharacteristics: Group 1 = population 202; Group 2= populations 209, 207 and 208 highlighted; Group 3 = populations 014, 015, 200, 203 and 206.

By analyzing four populations of $P$. aduncum, in the Federal District, Potzernheim et al. (2012) found different performances concerned to the essential oil composition and to the content of dilapiolle, regardless of the distance between them, pointing to the coexistence of varieties or chemotypes of the species in the same region. This contrasts with the hypothesis of Almeida et al. (2009), who point to the distribution patterns of these chemotypes according to environmental aspects such as climate, sunlight, soil, temperature and humidity, where the majority presence of dilapiolle in essential oil is limited to the populations of the Amazon region, possibly, due to the founder effect. 
Furthermore, Gaia et al. (2004) point to the influence of genetic factors of these possible chemotypes and concluded that it presents genetic diversity patterns that follows the local geographical distribution patterns, evidenced by efficient mechanisms of propagation of the species (Lepš et al., 2002). This result corroborated with Gottlieb et al. (1981), who subdivided the species in two varieties, cordulatum, found in the state of Amazonas, and aduncum, found in the state of Pará, with dilapiolle contents of 3.5 and $88.4 \%$ and $1.4 \%$ and $74.5 \%$, respectively. The same is true for $P$. hispidinervum to which Andrade et al. (2009) reported higher yields and safrole contents for individuals collected in the Amazon region. Moreover, according to Wadt \& Kageyama (2004), the species has great genetic variability within populations with a genetic structure that matches with the model of isolation by distance.

\section{CONCLUSIONS}

The morphological and phytochemical characterization of components of $A B G$ showed populations of Piper hispidinervum and P. aduncum with superior genetic material, particularly for the essential oil yield and contents of safrole and dilapiolle.

For $P$. hispidinervum, the region of Acrelândia and Plácido de Castro were the ones that originated the populations with the best target features, especially for populations 04 and 08 for content of safrole.

Regarding P. aduncum, populations 207, 208 and 209, from the micro-region of Cruzeiro do Sul presented the best target features.

These best-performing populations are suitable for selection in the breeding program, as superior genetic material in relation to the characteristics studied in this work.

\section{REFERENCES}

Almeida RRP, Souto RNP, Bastos CN, Silva MHL\& Maia JGS (2009)Chemical variation in Piper aduncum and biological properties of its dillapiole-rich essential oil. Chemistry \& Biodiversity, 6:14271434.

Andrade EH de A, Guimarães EF\& Maia JGS (2009)Variabilidade química em óleos essenciais de espécies de Piper da Amazônia. Belém, FEQ/UFPA. 448p.

Bergo CL, Sá CP, Pimentel FA, Mendonça HA, Sousa JA, Wadt LHO, Thomazini MJ\& Cavalcante MJB(2002)Cultivo da pimenta longa (Piper hispidinervum) na Amazônia Ocidental. Rio Branco, Embrapa Acre. 29p. (Sistemas de Produção,1).

Celis A, Mendonza C, Pachón M, Cardona J, Delgado W\& Cuca LE (2008)Extractos vegetales utilizados como biocontroladores con énfasis en la familia Piperaceae:una revisión. Agronomia Colombia, 26:97-106.
Estrela LLV, Fazolin M, Catani V, Alécio MR\& Lima MS(2006)Toxicidade de óleos essenciais de Piper aduncum e Piper hispidinervum em Sitophilus zeamais. Pesquisa Agropecuária Brasileira, 41:217-222.

Fazolin M,Estrela JVL,CataniV,Alécio MR\&Lima MS(2007)Propriedade inseticida dos óleos essenciais de Piper hispidinervum C. DC. Piper aduncum L. e Tanecium nocturnum (Barb. Rodr.) Bur. \& K. Shum sobre Tenebrio molitor L., 1758. Ciência e Agrotecnologia, 31:113-120.

Ferreira DF (2008)Sisvar:um programa para análise e ensino de estatística. Symposium, 6:36-41.

Ferreira PV (1991)Estatística experimental aplicada à agronomia. Maceió, EDUFAL. 437p.

Figueirêdo FJC, Alves SM, SantosAS\& Rocha Neto OG (2004)Rendimento e qualidade físico-química de óleo essencial extraído de diferentes composições da biomassa área de pimenta longa. Belém, Embrapa Amazônia Oriental. 31p. (Boletim de Pesquisa e Desenvolvimento, 33).

Gaia JMD, Mota MGC, ConceiçãoCCC, CostaMR\& Maia JGS (2004)Similaridade genética de populações naturais de pimenta-de-macaco por análise RAPD. Horticultura Brasileira, 22:686-689.

Gottlieb OR, Koketsu M, Magalhães MT, Maia JGS, Mendes PH, Rocha AI, Silva ML\& Wilberg VC(1981)Óleos essenciais da Amazônia VII. Acta Amazônica, 11:143-148.

Guimarães EF\& Giordano LCS (2004)Piperaceae do Nordeste brasileiro I: Estado do Ceará. Rodriguesia, 55:21-46.

Hair JF, Anderson RE, Tatham RL\& Black WC (2005)Análise multivariada de dados. Porto Alegre, Bookman. 593p.

Hartemink AE\& Sullivan NJN (2001)Leaf litter decomposition of Piper aduncum, Gliricidia sepium and Imperata cylindrica in the humid lowlands of Papua New Guinea. Plant and Soil, 230:115-124.

Heath HB (1977)Flavorings, condiments and relishes. In: Desrosier NW (ed.) Elements of Food Technology. Wesrport, The Avipublishing Company. p.666-701.

Ledo A S, Ledo FJS, Ritzinger R\& Cunha Sobrinho APC (1999)Portaenxertos para laranjeiras-doce (Citrus sinensis (L.) OSB.)em Rio Branco, Acre. Pesquisa Agropecuária Brasileira, 34:1211-1216.

Lepš J, Novotný V, Èí•ek L, Kenneth M, Issua B, Boen W, Kutil R, Auga J, Kasbal M, Manumbor M\& Hiuk S (2002)Successful invasion of the neotropical species Piper aduncum in rain forests in Papua New Guinea. Applied Vegetation Science,5:255-262.

Maia JGS,Zohhibi MGB, Andrade EHA, Santos AS, Silva MHLS, Luz AIR\& Bastos CN(1998)Constituents of the essential oil of Piper aduncum $\mathrm{L}$ growing wild in the Amazon region. Flavour and Fragrance Journal, 13:269-272.

Mesquita JMO,Cavaleiro C, Cunha AP, LombardiJÁ\& Oliveira AB (2005)Estudo comparativo dos óleos voláteis de algumas espécies de Piperaceae. Revista Brasileira de Farmacognosia, 15:6-12.

Miranda EM(2002)Caracterização e avaliação produtiva de uma população nativa de pimenta longa (Piper hispidinervum C.DC) no Seringal Cachoeira, AC., Brasil. Acta Amazonica, 32:9-20.

Navickiene HMD,Morandim AA, Alécio AC, Regasini LO, BergamoDCB, Telascrea M, Cavalheiro AJ, Lopes MN, Bolzani VS, Furlan M, Marques MOM, Young MM\& Kato MJ (2006) Composition and antifungal activity of essential oils from Piper aduncum, Piper arboreum and Piper tuberculatum. Química Nova, 29:467-470.

Pimentel FA, Cardoso M das G, Salgado APSP, Aguiar PM, Silva V de F, Morais AR de\& Nelson DL (2006)A convenient method for the determination of moiture in aromatic plants. Química Nova, 29:373-375.

Potzernheim MCL,Bizzo HR,Silva JP\& Vieira RF (2012)Chemical characterization of essential oil constituents of four populations of Piper aduncum L. from Distrito Federal, Brazil. Biochemical Systematics and Ecology, 42:25-31.

Rev. Ceres, Viçosa, v. 62, n.1, p. 078-086, jan/fev, 2015 
Santos AS, Alaves SM, Figueirêdo FJC\& Rocha Neto OG (2004)Descrição de sistema e de métodos de extração de óleos essenciais e determinação de umidade de biomassa em laboratório. Belém, Embrapa Amazônia Oriental. 6p. (Comunicado Técnico, 99).

Silva ACPR\& Oliveira MN (2000)Caracterização botânica e química de três espécies do gênero Piper no Acre. Rio Branco, Embrapa Acre. 13p. (Boletim de Pesquisa, 23).

Silva ESA, Rocha Neto OG\& Figueirêdo FJC (2002)Respostas biofísicas, alocação de biomassa e produção de óleo essencial de "pimenta longa" no munícipio de Igarapé-Açu, PA-Brasil. Acta Horticulturae, 569:129-136.
Smith RM\& Kassim H (1979)The essencial oil of Piper aduncum from Fiji. New Zealand Journal of Science, 22:127-8.

Statsoft INC (1995)Statistica for Windows - computer program manual. Tulsa, StatSoft. 322p.

Wadt LHO\& Kageyama PY (2004)Estrutura genética e sistema de acasalamento de Piper Hispidinervum. Pesquisa Agropecuária Brasileira, 39:151-157.

Yoneda T (2006)Fruit production and leaf longevity in the tropical shrub Piper aduncum L. in Sumatra. Tropics, 15:209-217. 